\title{
PENGARUH KECEMASAN TERHADAP KADAR GULA DARAH PADA PENDERITA DIABETES MELITUS DI RSUD SYEKH YUSUF GOWA
}

\author{
Effect Of Anxiety On Blood Sugar Levels In Diabetes Melitus Patients In Syekh Yusuf Gowa Hospital
}

\author{
Ariskawati' , H.Bahtiar2, H.Muh.Yusuf 3 \\ Poltekkes Kemenkes Makassar \\ Ariskawati2505@gmail.com
}

\section{ABSTRAK}

Kecemasan pada penderita diabetes melitus dikarenakan bahwa diabetes dianggap merupakan suatu penyakit yang menakutkan, karena mempunyai dampak negatif yang kompleks terhadap kelangsungan kecemasan individu. Kadar gula darah yang meningkat merupakan efek umum dari diabetes tak terkontrol. Diabetes Melitus adalah penyakit kronis yang terjadi ketika pankreas tidak menghasilkan cukup insulin atau tubuh tidak dapat secara efektif menggunakan insulin yang dihasilkan oleh pangkreas Penelitian ini bertujuan untuk mengetahui pengaruh kecemasan terhadap kadar gula darah pada penderita diabetes melitus di RSUD Syekh Yusuf Gowa. Jenis penelitian ini merupakan penelitian kuantitatif dengan pendekatan cross sectional. Sampel diambil secara Purposive Sampling berjumlah 20 responden. Penelitian ini dilakukan mulai pada tanggal 31 April sampai 30 Mei 2018. Pengumpulan data primer dengan menggunakan kuesioner dan lembar observasi kadar gula darah. Berdasarkan hasil dari uji statistik (uji t tidak berpasangan) yang menunjukkan bahwa ada pengaruh yang signifikan antara kecemasan terhadap kadar gula darah pada penderita diabetes melitus dengan $p_{\text {value }}=0,002(\mathrm{a}=0,05)$.

Kata Kunci : Kecemasan, Kadar gula darah, Diabetes melitus

\section{ABSTRACT}

Anxiety in people with diabetes mellitus due to diabetes is considered a frightening disease, because it has a complex negative impact on the survival of anxiety individuals. Increased blood sugar levels are a common effect of uncontrolled diabetes. Diabetes Mellitus is a chronic disease that occurs when the pancreas does not produce enough insulin or the body can not effectively use insulin produced by pangkreas This study aims to determine the effect of anxiety on blood sugar levels in people with diabetes mellitus in RSUD Syekh Yusuf Gowa. This type of research is a quantitative research. Samples taken by Purposive Sampling amounted to 20 respondents. This study was conducted from April 31 to May 30, 2018. Primary data collection using questionnaires and blood sugar observation sheets. Based on the results of statistical tests (unpaired t-test) showed that there was a significant effect between anxiety on blood sugar levels in people with diabetes mellitus with pvalue $=0.002(\alpha=0.05)$.

Keywords : anxiety, blood sugar levels, diabetes mellitus

\section{PENDAHULUAN}

Penyakit diabetes adalah penyakit kronis yang terjadi ketika pankreas tidak menghasilkan cukup insulin atau ketika tubuh tidak dapat secara efektif menggunakan insulin yang dihasilkan oleh pankreas. Kadar gula darah yang meningkat merupakan efek umum dari diabetes tak terkontrol. Dimana pada tingkat tertentu bisa menyebabkan kerusakan serius pada banyak sistem tubuh, khususnya saraf dan pembuluh darah. (Muflihatin \& Saputra, 2016).

World Health Organization (WHO) diperkirakan 422 juta orang dewasa hidup dengan diabetes pada tahun 2014, dibandingkan dengan 108 juta pada tahun 1980. Prevalensi global Diabetes dengan standar usia hampir dua kali lipat sejak 1980, meningkat dari $4,7 \%$ menjadi $8,5 \%$ pada populasi orang dewasa. Hal ini mencerminkan peningkatan faktor risiko terkait seperti kelebihan berat badan atau obesitas.Selama dekade terakhir, prevalensi Diabetes telah meningkat lebih cepat di negara berpenghasilan rendah dan menengah daripada di negara-negara berpenghasilan tinggi.(WHO, 2016). International Diabetes Federation (IDF) telah merilis perkiraan baru mengenai prevalensi diabetes di seluruh dunia, yang menunjukkan bahwa 1 dari 11 orang dewasa saat ini hidup dengan diabetes, 10 juta lebih banyak dari pada tahun 2015 (IDF, 2017).

Riskesdas menunjukkan bahwa terjadi peningkatan prevalensi Diabetes di Indonesia dari $5,7 \%$ tahun 2007 menjadi 6,9\% atau sekitar sekitar 9,1 juta pada tahun 2013. Seperti kondisi di dunia, Diabetes kini menjadi salah satu penyebab kematian terbesar di Indonesia (Depkes, 2016).

Badan Pusat Statistik Sulawesi Selatan menyatakan bahwa penyakit Diabetes Melitus menduduki posisi ketiga dari 10 jumlah kasus penyakit terbanyak di Provinsi Sulawesi Selatan dengan 17.843 kasus, setelah Hipertensi dengan 81.462 kasus, kecelakaan lalu lintas dengan 22.905 kasus, di posisi keempat ada PKD dengan 12.417 kasus, dilanjutkan dengan kanker 5.920 kasus, kanker payudara 3.036 kasus, obesitas 2.671 kasus, Struma 2.442 kasus, osteoporosis 1.737 kasus dan Penyakit Ginjal Kronik 726 kasus. (BPS Sulsel, 2015).

Hasil survey data awal yang peneliti peroleh dari pendokumentasian di Ruang Rekam Medik RSUD Syekh Yusuf Gowa periode 2018, dari data dua bulan terakhir didapatkan populasi yang menderita Diabetes Melitus sebanyak 41 orang. 
Kecemasan pada penderita Diabetes Melitus dikarenakan bahwa diabetes dianggap merupakan suatu penyakit yang menakutkan, karena mempunyai dampak negatif yang kompleks terhadap kelangsungan kecemasan individu. Kecemasan terjadi karena seseorang merasa terancam baik secara fisik maupun psikologis (Jauhari, 2016).

Penyakit fisik dapat mengakibatkan kecemasan pada seseorang. Kurang lebih 5-10\% masyarakat umum mengalami kecemasan. Hasil survey persatuaan Dokter Spesialis Kesehatan Jiwa (PDSKJ) yang diumumkan bulan juni 2007 yang lalu maka hampir semua orang di Indonesia sedang mengalami kecemasan. Menurut survey ini $94 \%$ masyarakat Indonesia mengidap kecemasan dari tingkat ringan hingga yang paling berat.

Kecemasan telah diprediksi oleh WHO sebagai penyebab masalah utama pada tahun 2020 dan sebagai penyakit kedua di dunia setelah jantung skemik. Seseorang dengan mengalami penyakit kronis, rentang mengalami kecemasan salah satunya adalah penderita Diabetes. Hasil penelitian David (2004) terdapat $48 \%$ penderita Diabetes mengalami kecemasan akibat penyakitnya. Badan Kesehatan Dunia mencatat $27 \%$ pasien Diabetes Melitus mengalami kecemasan (Murdiningsih \& Ghofur, 2013).

Berdasarkan gambaran permasalahan di atas maka peneliti termotivasi untuk melakukan penelitian mengenai "Pengaruh kecemasan terhadap kadar gula darah pada penderita Diabetes Melitus di RSUD Syekh Yusuf Gowa"

\section{METODE PENELITIAN}

\section{Jenis dan Desain Penelitian}

Penelitian ini menggunakan jenis penelitian kuantitatif dengan pendekatan cross sectional

\section{Populasi, sampel dan sampling}

Populasi

Pada penelitian ini populasinya adalah penderita Diabetes Melitus yang di Rawat di RSUD Syekh Yusuf Gowa

Sampel

Sampel dalam penelitian ini adalah pasien Rawat Inap di RSUD Syekh Yusuf Gowa

Teknik sampling

Teknik sampling yang digunakan dalam penelitian ini adalah dengan menggunakan teknik purposive sampling

\section{HASIL PENELITIAN DAN PEMBAHASAN}

Penelitian ini dilakukan dari tanggal 30 April sampai 31 Mei 2018. Penelitian ini dilaksanakan melalui penyebaran kuisioner dan lembar observasi kadar gula darah responden.

Sampel yang digunakan adalah semua pasien Diabetes Melitus yang dirawat d RSUD syekh yusuf gowa. Banyaknya sampel pada populasi yang sesuai dengan kriteria inklusi tersebut langsung dijadikan subjek penelitian. Penelitian ini menggunakan sampel sebanyak 20 responden pasien Diabetes Melitus.

Setelah dilakukan pengumpulan data, selanjutnya dilakukan pengolahan data untuk memperoleh hasil dari penelitian ini. Data diolah ke dalam SPSS dan kemudian disajikan dalam bentuk tabel distribusi frekuensi dan narasi yang meliputi karakteristik responden (jenis kelamin, umur responden, pendidikan, pekerjaan) dan variabel yang diteliti yaitu tingkat kecemasan dan kadar gula darah. Berdasarkan hasil penelitian diperoleh data peneiltian yang disajikan sebagai berikut:

Karakteristik Responden

Jenis kelamin

Tabel 4.1

Distribusi responden berdasarkan jenis kelamin di RSUD Syekh Yusuf Gowa

\begin{tabular}{|c|c|c|}
\hline Jenis kelamin & frekuensi & $\%$ \\
\hline Laki-laki & 8 & 40 \\
\hline Perempuan & 12 & 60 \\
\hline Total & 20 & 100 \\
\hline
\end{tabular}

Berdasarkan tabel 4.1 menunjukkan bahwa dari 20 responden yang paling banyak adalah perempuan 12 $(60 \%)$ responden, dan laki-laki 6 (40\%) responden.

Umur

Tabel 4.2

Distribusi responden berdasarkan umur Di RSUD Syekh Yusuf Gowa

\begin{tabular}{|c|c|c|}
\hline Umur & frekuensi & $\%$ \\
\hline 48-53 Tahun & 4 & 20 \\
\hline 54-59 Tahun & 7 & 35 \\
\hline 60-65 Tahun & 6 & 30 \\
\hline 66-71 Tahun & 3 & 15 \\
\hline Total & 20 & 100 \\
\hline
\end{tabular}

Berdasarkan tabel 4.2 menunjukkan bahwa dari 20 responden yang paling banyak adalah umur antara 54-59 tahun sebanyak 7 (35\%) responden, 60-65 tahun sebanyak $6(30 \%)$ responden, 48-53 tahun yaitu $4(20 \%)$ responden, $66-71$ tahun sebanyak 3 (15\%).

\section{Pendidikan}

Tabel 4.3

Distribusi tabel berdasarkan pendidikan responden Di RSUD Syekh Yusuf Gowa

\begin{tabular}{|c|c|c|}
\hline Pendidkan & frekuensi & $\%$ \\
\hline SD & 3 & 15 \\
\hline SMP & 8 & 40 \\
\hline SMA & 5 & 25 \\
\hline Perguruan Tinggi & 4 & 20 \\
\hline Total & 20 & 100 \\
\hline
\end{tabular}

Berdasarkan tabel 4.3 menunjukkan bahwa dari 20 responden,di antaranya responden paling banyak 
memiliki pendidikan SMP terdapat $8 \quad(40 \%)$ responden, SMA sebanyak $5(25 \%)$ responden, Perguruan tinggi sebanyak $4(20 \%)$ responden, dan SD sebanyak $3(15 \%)$ responden.

\section{Pekerjaan}

Tabel 4.4

Distribusi tabel berdasarkan pekerjaan Di RSUD Syekh Yusuf Gowa

\begin{tabular}{|c|c|c|}
\hline Pekerjaan & frekuensi & $\%$ \\
\hline PNS & 3 & 15 \\
\hline WIRASWASTA & 6 & 30 \\
\hline IRT & 10 & 50 \\
\hline PENSIUN & 1 & 5 \\
\hline Total & 20 & 100 \\
\hline
\end{tabular}

Berdasarkan Tabel 4.4 menunjukkan bahwa dari 20 responden, paling banyak responden memiliki pekerjaan ibu rumah tangga sebanyak $10(50 \%)$ responden, wiraswasta sebanyak $6 \quad(30 \%)$ Distribusi pengukuran kadar gula darah pertama responden, pns sebanyak $3(15 \%)$ responden, dan paling sedikit pensiun sebanyak $1(5 \%)$ responden.

\section{Analisis Univariat}

Dalam analisis univariat dihasilkan distribusi frekuensi dari masing-masing variabel penelitian, baik variabel dependent dan variabel independent.

\section{Kecemasan}

Tabel 4.5

Distribusi tabel berdasarkan kecemasan responden di RSUD Syekh Yusuf Gowa

\begin{tabular}{|c|c|c|}
\hline Kecemasan & frekuensi & $\%$ \\
\hline Ringan & 7 & 35 \\
\hline Sedang & 13 & 65 \\
\hline Total & 20 & 100 \\
\hline
\end{tabular}

Berdasarkan tabel 4.5 menunjukkan bahwa dari 20 responden yang paling banyak memiliki kecemasan sedang sebanyak $13(65 \%)$ responden, kecemasan ringan sebanyak 7 (35\%) responden.

Tabel 4.6

Distribusi pengukuran kadar gula darah pertama

\begin{tabular}{|c|c|c|c|c|c|c|}
\hline $\begin{array}{c}\text { Kadar Gula } \\
\text { Darah }\end{array}$ & $\mathbf{n}$ & Mean & Median & SD & Min-Mak & $\mathbf{9 5 \%} \mathbf{C l}$ \\
\hline $\begin{array}{c}\text { Kecemasan } \\
\text { Ringan }\end{array}$ & 7 & 229 & 194 & 104 & $130-385$ & $132,55-325,45$ \\
\hline $\begin{array}{c}\text { Kecemasan } \\
\text { Sedang }\end{array}$ & 13 & 243 & 224 & 85,13 & $137-417$ & $191,71-294,60$ \\
\hline
\end{tabular}

Tabel 4.6 menunjukkan bahwa rata-rata pengukuran kadar gula darah pertama sebelum mengalami kecemasan ringan adalah $229 \mathrm{mg} / \mathrm{dl}(95 \% \mathrm{Cl}$ : 132,55-325,45) dengan standar deviasi $104 \mathrm{mg} / \mathrm{dl}$. Kadar gula darah terendah $130 \mathrm{mg} / \mathrm{dl}$ dan dan tertinggi $385 \mathrm{mg} / \mathrm{dl}$. Hasil estimasi interval dapat disimpulkan bahwa rata-rata kadar gula darah pertama sebelum mengalami kecemasan ringan yaitu 132,55-325,45 mg/dl.

Distribusi Pengukuran Kadar Gula Darah Kedua

Tabel 4.7

Distribusi pengukuran kadar gula darah kedua

\begin{tabular}{|c|c|c|c|c|c|c|}
\hline Kadar Gula Darah & $\mathbf{n}$ & Mean & Median & SD & Min-Mak & $\mathbf{9 5 \%} \mathbf{C l}$ \\
\hline $\begin{array}{c}\text { Setelah } \\
\text { Kecemasan Ringan }\end{array}$ & 7 & 193 & 191 & 35,57 & $149-238$ & $159,67-225,47$ \\
\hline Kecemasan Sedang & 13 & 295 & 268 & 87,04 & $178-441$ & $242,25-347,25$ \\
\hline
\end{tabular}

Tabel 4.7 menunjukkan bahwa rata-rata kadar gula darah kedua setelah mengalami kecemasan ringan adalah 193 mg/dl (95\% Cl: 159,67-225,47) dengan standar deviasi $35,57 \mathrm{mg} / \mathrm{dl}$. Kadar gula darah terendah $149 \mathrm{mg} / \mathrm{dl}$ dan dan tertinggi $238 \mathrm{mg} / \mathrm{dl}$. Hasil estimasi interval dapat disimpulkan bahwa ratarata kadar gula darah kedua setelah mengalami kecemasan ringan yaitu 159,67-225,47 mg/dl.
Rata-rata pengukuran kadar gula darah pertama sebelum mengalami kecemasan sedang adalah 243 $\mathrm{mg} / \mathrm{dl}$ (95\% Cl: 191,71-294,60) dengan standar deviasi 85,13 mg/dl. Kadar gula darah terendah 137 $\mathrm{mg} / \mathrm{dl}$ dan dan tertinggi $417 \mathrm{mg} / \mathrm{dl}$. Hasil estimasi interval dapat disimpulkan bahwa rata-rata kadar gula darah sebelum mengalami kecemasan sedang yaitu 191,71-294,60 mg/dl.

Rata-rata kadar gula darah kedua setelah mengalami kecemasan sedang adalah $295 \mathrm{mg} / \mathrm{dl}(95 \% \mathrm{Cl}$ : $242,25-347,25)$ dengan standar deviasi $87,64 \mathrm{mg} / \mathrm{dl}$. Kadar gula darah terendah $178 \mathrm{mg} / \mathrm{dl}$ dan dan tertinggi $441 \mathrm{mg} / \mathrm{dl}$. Hasil estimasi interval dapat disimpulkan bahwa rata-rata kadar gula darah kedua setelah mengalami kecemasan sedang yaitu 242,25 $347,25 \mathrm{mg} / \mathrm{dl}$. 
Tabel 4.8

Uji normalitas kadar gula darah pertama sebelum mengalami kecemasan ringan dan sedang pada penderita diabetes melitus

\begin{tabular}{|c|c|c|}
\hline $\begin{array}{c}\text { Kadar gula darah } \\
\text { pertama }\end{array}$ & $\mathrm{n}$ & Shapiro-wilk \\
\cline { 3 - 3 } & & Sig \\
\hline Kecemasan ringan & 7 & 0,067 \\
\hline Kecemasan sedang & 13 & 0,070 \\
\hline
\end{tabular}

Berdasarkan hasil uji normalitas data menggunakan uji Shapiro-Wilk Kadar gula darah pertama sebelum mengalami kecemasan ringan diperoleh nilai $p=0,067$ dan sebelum mengalami kecemasan sedang $p=0,070$, sehingga memenuhi syarat untuk dilakukan uji t tidak berpasangan.

Tabel 4.9

Uji normalitas kadar gula darah kedua setelah mengalami kecemasan ringan dan sedang pada penderita diabetes melitus

\begin{tabular}{|c|c|c|}
\hline Kadar gula darah kedua & $\mathrm{n}$ & $\begin{array}{c}\text { Shapiro- } \\
\text { Wilk }\end{array}$ \\
\cline { 3 - 3 } & & Sig \\
\hline Kecemasan ringan & 7 & 0,243 \\
\hline Kecemasan sedang & 13 & 0,228 \\
\hline
\end{tabular}

Berdasarkan hasil uji normalitas data menggunakan uji Shapiro-Wilk kadar gula darah kedua setelah mengalami kecemasan ringan diperoleh nilai $p=0,243$ dan setelah mengalami kecemasan sedang $p=0,228$, sehingga memenuhi syarat untuk dilakukan uji t tidak berpasangan.

\section{Analisis Bivariat}

Analisis Bivariat digunakan untuk mengetahui pengaruh kecemasan terhadap kadar gula darah pada penderita Diabetes Melitus.

Pengaruh Kecemasan terhadap Kadar Gula Darah pada penderita Diabetes Melitus

Tabel 4.10

Pengaruh kecemasan terhadap kadar gula darah pada penderita diabetes melitus di RSUD Syekh Yusuf Gowa

\begin{tabular}{|c|c|c|c|c|}
\hline Kecemasan & \multirow{N}{*}{} & \multicolumn{2}{|c|}{$\begin{array}{c}\text { Rata-rata kadar gula } \\
\text { darah }\end{array}$} & $\begin{array}{c}\mathrm{P} \\
\text { value }\end{array}$ \\
\cline { 3 - 4 } & & Pertama & Kedua & \\
\hline Ringan & 7 & 229 & 193 & 0,002 \\
\hline Sedang & 13 & 243 & 295 & \\
\hline
\end{tabular}

*uji t tidak berpasangan dengan $a<0,05$

Tabel 4.10 menunjukkan, rata-rata kadar gula darah pertama sebelum mengalami kecemasan ringan 229, sedangkan rata-rata kadar gula darah pertama sebelum mengalami kecemasan sedang lebih tinggi yaitu 243.dan rata-rata kadar gula darah kedua setelah mengalami kecemasan ringan 193, sedangkan rata-rata kadar gula darah kedua setelah mengalami kecemasan sedang lebih tinggi yaitu 295. Hasil analisis menggunakan uji t tidak berpasangan menunjukkan ada perbedaan kadar gula darah kedua setelah mengalami kecemasan ringan dan kecemasan sedang pada penderita Diabetes Miletus $(p=0,002)$. Hal ini menunjukkan ada pengaruh kecemasan terhadap kadar gula darah penderita Diabetes Melitus.

\section{PEMBAHASAN}

Berdasarkan hasil pengolahan data yang didapatkan dan disesuaikan dengan tujuan penelitian yaitu untuk mengetahui pengaruh kecemasan terhadap kadar gula darah pada penderita diabetes melitus. Maka sistematika pembahasan diuraikan sebagai berikut:

\section{Kecemasan}

Berdasarkan hasil penelitian didapatkan jumlah responden yang mengalami kecemasan ringan sebanyak $7 \quad(35 \%)$ orang, Sedangkan yang mengalami kecemasan sedang sebanyak 13 (65\%) orang. Kecemasan ini dapat disebabkan oleh penyakit fisik atau keabnormalan,bukan karena konflik emosional. Kecemasan ini termasuk kecemasan sekunder. Kecemasan dapat juga disebabkan oleh banyak faktor diantaranya faktor biologis, psikologis dan sosial. Faktor biologik kecemasan dapat ditimbulkan akibat reaksi saraf otonom yang berlebihan dengan meningkatnya respon saraf simpatis, terjadi pelepasan ketokolamin dan naiknya metabolisme norepineprin 3-metoksil4dehidrosifenil-glikol (MHPG). Orang yang menderita penyakit DM dapat menyebabkan timbulnya kecemasan dikarenakan penyakit ini merupakan penyakit kronis dan dapat timbul berbagai komplikasi dan dapat memperpendek umur serta memerlukan pengobatan seumur hidup. Kecemasan dapat mempengaruhi pengendalian gula darah(Wiyadi, Loriana, Lusty Junita, 2013).

\section{Kadar Gula Darah}

a). Pengukuran kadar gula darah pertama

Tabel 4.6 menunjukkan bahwa rata-rata pengukuran kadar gula darah pertama sebelum mengalami kecemasan ringan adalah $229 \mathrm{mg} / \mathrm{dl} \quad(95 \% \mathrm{Cl}$ : 132,55-325,45) dengan standar deviasi $104 \mathrm{mg} / \mathrm{dl}$. Kadar gula darah terendah $130 \mathrm{mg} / \mathrm{dl}$ dan dan tertinggi $385 \mathrm{mg} / \mathrm{dl}$. Hasil estimasi interval dapat disimpulkan bahwa rata-rata kadar gula darah pertama sebelum mengalami kecemasan ringan yaitu 132,55-325,45 mg/dl.

Rata-rata kadar gula darah pertama sebelum mengalami kecemasan sedang adalah $243 \mathrm{mg} / \mathrm{dl}$ (95\% Cl: 191,71-294,60) dengan standar deviasi $85,13 \mathrm{mg} / \mathrm{dl}$. Kadar gula darah terendah $137 \mathrm{mg} / \mathrm{dl}$ dan dan tertinggi $417 \mathrm{mg} / \mathrm{dl}$. Hasil estimasi interval dapat disimpulkan bahwa rata-rata kadar gula darah 
pertama sebelum mengalami kecemasan sedang yaitu 191,71-294,60 mg/dl.

b). Pengukuran kadar gula darah kedua

Tabel 4.7 menunjukkan bahwa rata-rata pengukuran kadar gula darah kedua setelah mengalami kecemasan ringan adalah $193 \mathrm{mg} / \mathrm{dl}(95 \% \mathrm{Cl}$ : 159,67-225,47) dengan standar deviasi 35,57 mg/dl. Kadar gula darah terendah $149 \mathrm{mg} / \mathrm{dl}$ dan dan tertinggi $238 \mathrm{mg} / \mathrm{dl}$. Hasil estimasi interval dapat disimpulkan bahwa rata-rata kadar gula darah setelah mengalami kecemasan ringan yaitu 159,67$225,47 \mathrm{mg} / \mathrm{dl}$.

Rata-rata pengukuran kadar gula darah kedua setelah mengalami kecemasan sedang adalah 295 $\mathrm{mg} / \mathrm{dl} \quad(95 \%$ Cl: $242,25-347,25)$ dengan standar deviasi $87,64 \mathrm{mg} / \mathrm{dl}$. Kadar gula darah terendah 178 $\mathrm{mg} / \mathrm{dl}$ dan dan tertinggi $441 \mathrm{mg} / \mathrm{dl}$. Hasil estimasi interval dapat disimpulkan bahwa rata-rata kadar gula darah setelah mengalami kecemasan sedang yaitu 242,25-347,25 mg/dl.

Kadar gula darah adalah istilah yang mengacu kepada tingkat glukosa di dalam darah. Glukosa dalam tubuh berfungsi sebagai sumber energi atau kalori. Glukosa dalam darah berasal dari penyerapan usus dari makanan yang mengandung karbohidrat dan sebagian dari pemecahan simpanan energi dalam jaringan (glikogen). Konsentrasi gula darah atau tingkat glukosa serum, diatur dengan ketat di dalam tubuh. Umumnya tingkat gula darah bertahan pada batas-batas yang sempit sepanjang hari (70$150 \mathrm{mg} / \mathrm{dl}$ ). Tingkat ini meningkat setelah makan dan biasanya berada pada level terendah pada pagi hari, sebeum makan (Kurnia dan Prawesti, 2017).

Pengaturan kadar glukosa darah pada keadaan normal glukosa dipertahankan antara 70-110mg/dl. Selama periode puasa pankreas secara terus menerus mensekresi insulin dalam jumlah sedikit, sementara glukagon dilepaskan ketika kadar glukosa menurun menstimulasi hati untuk melepaskan cadangan glukosanya. Sehingga insulin dan glukagon bersama-sama berperan dalam mempertahankan kadar glukosa darah. Setelah 8-12 jam tanpa makanan, hati akan memecah glikogen dari non karbohidrat, termasuk asam amino menjadi glukosa, yang kemudian dimanfaatkan sel untuk metabolisme dan energi sel (Tarwoto, 2012).

Penderita Diabetes Melitus identik dengan tingginya kadar glukosa dalam darah, untuk itu perlunya dilakukan pengendalian glukosa darah. Pengendalian kadar glukosa darah yang baik dan optimal untuk mencegah terjadinya komplikasi kronik.

Pengaruh kecemasan terhadap kadar gula darah pada penderita diabetes melitus

Berdasarkan hasil uji uji $t$ tidak berpasangan menunjukkan ada perbedaan kadar gula darah kedua setelah mengalami kecemasan ringan dan kecemasan sedang pada penderita Diabetes Melitus $(p=0,002)$. Hal ini menunjukkan ada pengaruh kecemasan terhadap kadar gula darah pada penderita Diabete Melitus. Pasien yang menderita diabetes melitus dapat menimbulkan kecemasan terutama yang telah timbul komplikasi. Kecemasan dapat meningkatkan kadar gula darah meskipun pada HBA1c lemah kemaknaannya.

Murdiningsih dan Ghofur (2013) dalam penelitiannya menunjukkan bahwa ada pengaruh kecemasan terhadap kadar gula darah pada penderita diabetes melitus.

Penderita diabetes melitus memiliki tingkat kecemasan yang berkaitan dengan penyakit dan pengobatan yang harus dijalani dan terjadinya komplikasi serius. Kecemasan dapat menyebabkan semakin memburuknya kondisi kesehatan atau penyakit yang diderita oleh seseorang. Penderita diabetes melitus jika mengalami kecemasan yang tinggi akan mempengaruhi proses kesembuhan dan menghambat kemampuan aktivitas kehidupan sehari-hari.

Penyakit diabetes melitus dapat menimbulkan kecemasan terutama yang sudah kronis dan timbul komplikasi,disisi lain kecemasan pada penderita diabetes melitus dapat meningkatkan kadar gula darah (hiperglikemia),untuk itu edukasi pada penderita diabetes melitus sangat dibutuhkan guna mengurangi tingkat kecemasan dan mengontrol kadar gula darah.

\section{KESIMPULAN}

1. Sebagian besar pasien diabetes melitus di RSUD Syekh Yusuf Gowa mengalami kecemasan sedang

2. kadar gula darah pertama sebelum mengalami kecemasan sedang yaitu $243 \mathrm{mg} / \mathrm{dl}$. Dan kadar gula darah kedua setelah mengalami kecemasan sedang yaitu $295 \mathrm{mg} / \mathrm{dl}$.

3. Ada pengaruh yang signifikan kecemasan terhadap kadar gula darah pada penderita diabetes melitus $\mathrm{P}_{\text {value }}=0,002$ dengan demikian $\mathrm{HO}$ diterima

\section{SARAN}

1. Bagi institusi pendidikan diharapkan sebagai informasi yang dapat dijadikan referensi bagi mahasiswa lain yang ingin melakukan penelitian lanjutan

2. Bagi lahan rumah sakit diharapkan memberikan pendidikan kesehatan kepada pasien diabetes melitus guna mengurangi tingkat kecemasan agar kadar gula darah dapat terkontrol

3. Bagi peneliti selanjutnya diharapkan perlu melakukan penelitian dengan menggunakan metode yang lain dan memiliki sampel yang 
lebih banyak sehingga hasil penelitian lebih optimal.
4. Bagi penderita Diabetes Melitus diharapkan mengurangi tingkat kecemasan dan mengontrol kadar gula darah agar tidak terjadi komplikasi.

\section{DAFTAR PUSTAKA}

BPS Sulsel.(2015). Jumlah Kasus 10 Penyakit Terbanyak di Provinsi Sulawesi Selatan,2015.https://sulsel.bps.go.id/linkTableDinamis/view/id/290. Diakses tanggal 03 Februari 2018

Depkes. (2016). Mari Kita Cegah Diabetes dengan Cerdik. http://www.depkes. go.id/article/print/16040700002/menkes-mari-kita-cegah-diabetes-dengan-cerdik.html. Diakses tanggal 03 Februari 2018

Damayanti,Santi.( 2015). Diabetes melitus dan penalataksanaan keperawatan.yogyakarta: Nuha Medika Hidayat, A. Aziz Alimul.( 2017). Metodologi Penelitian Keeperawatan dan Kesehatan. Jakarta: Salemba Medika Hawari Dadang. (2016). Manajemen Stress Csemas Dan Depresi. Jakarta: FKUI

IDF. (2017). New IDF figures show continued increase in diabetes across the globe, reiteratingtheneedforurgentaction. https://www.idf. org/news/94:new -idf-figures-show-continuedincrease-in-diabetes-across-the-globe,-reite rating-the-need-for-urgent-action.html. Diakses tanggal 03 Februari 2018

Jauhari. (2016). Dukungan Sosial Dan Kecemasan Pada Pasien Diabetes Melitus. http://jurnal.unmuhjember.ac.id. Diakses tanggal: 04 Februari 2018

Kurnia, E., \& Prawesti, D. (2017). Senam kaki bagi pasien diabetes melitus. Nganjuk: Adjie Media Nusantara Murdiningsih Dyah Surti \& Ghofur,Gun Gun Abdul. (2013). Pengaruh Kecemasan Terhadap Kadar Gula Darah Pada Penderita Diabetes Melitus Di Wilayah Puskesmas Banyuanyar Surakarta.http://download .portalgaruda. Diakses tanggal: 4 Februari 2018

Muflihatin Siti Khoiroh \& Saputra Rahmat Indra. (2016). Hubungan Tingkat Pengetahuan Tentang Senam Kaki Diabetik Dengan Aktivitas Senam Kaki Diabetik Untuk Mencegah Ulkus Diabetik Pada Penderita Diabetes Melitus Di Wilayah Kerja Puskesmas Loa Kulu. http://ojs .stikesmuda .ac.id/index.php/ilmu-kesehatan larticle/ view/53/pdf. Diakses tanggal: 03 Februari 2018

Notoatmodjo. (2015). Metodologi Penelitian Kesehatan. Jakarta : Rineka Cipta Nursalam. (2016). Metodologi penelitian ilmu keperawatan : pendekatan praktis edisi 4. Jakarta: salemba medika Prabowo,Eko. (2014). Konsep \& aplikasi asuhan keperawatan jiwa.Yogyakarta:Nuha Medika Rumahorbo, H. (2014). Mencegah Diabetes Mellitus dengan Perubahan Gaya Hidup.Bogor: In Media

Saryono \& Anggraeni.M.D, (2017). Metodologi penelitian kualitatif dan kuantitatif dalam bidan kesehatan.Yogyakarta: Nuha Medika

Seriani Nopia, Lestari Puji, \& Wahyuni Sri. (2016). Hubungan Kebiasaan Olahraga dengan Tingkat Stress pada Penderita Diabetes Melitus di Wilayah Kerja Puskesmas Bergas Kabupaten Semarang. Diakses tanggal: 04 Februari 2018

Suyono, S. (2015). Penatalaksanaan Diabetes Melitus Terpadu. Jakarta: Balai Penerbit FKUI.

Tarwoto. (2012). Keperawatan Medikal Bedah Sistem Endokrin. Jakarta : Trans Info Media 
Jurnal Media Keperawatan: Politeknik Kesehatan Makassar

Vol. 08. No 022017

e-issn : 2622-0148, p-issn : 2087-0035

Wijaya, Andra saferi \& Putri, Yessie Mariza. (2013). KMB 2 Keperawatan Medikal Bedah (Keperawatan dewasa).Yogyakarta: Nuha Medika

WHO. (2016). World Health Day 2016: WHO calls for global action to halt rise in and improve care for people with diabetes. http://www.who.int /mediacentre/ news/releases/2016/world-health-day/en/Diakses tanggal 03 Februari 2018

Wiyadi, Loriana Rina \& Lusty Junita. (2013). Hubungan Tingkat Kecemasan Dengan Kadar Gula Darah Pada Penderita Diabetes Melitus.https://husadamahakam.files. wordpress.com/2015/07/1-wiyadi-263271.pdf.Diakses tanggal: 03 Februari 2018 